\title{
A STUDY OF MATRICES FOR HIGH-INTENSITY MAGNETIC SEPARATORS
}

\author{
V.M. MALY \\ Mekhanobrchermet Institute, 324087 Krivoy Rog, Ukraine
}

Abstract: This paper summarises the results of the research carried out, for the last 15 years, by the Department of Separation of Weakly Magnetic Ores of the Mekhanobrchermet Institute, Krivoy Rog, Ukraine, on the matrices of high-intensity magnetic separators foe beneficiation of weakly magnetic iron ores and other weakly magnetic materials.

(Received March 19, 1994, revised June 27, 1994)

\section{INTRODUCTION}

One of the basic technological elements of high-intensity magnetic separators (HIMS) is the separation matrix. The role of the matrix and the requirements it must meet are as follows:

* Concentration of the magnetic field in the separation zone of the separator

* Creation of the magnetic field gradient

* Penetrability of the non-magnetic particles through the matrix elements

* Accumulation of paramagnetic particles on the matrix elements

$\star \quad$ The cleaning of the matrix elements from paramagnetic particles outside the magnetic field

* Mechanical strength under the conditions of the polarity reversals in the magnetic field. 
History of the development of high-intensity magnetic separators is associated with the application of matrices as diverse as drilling shot, steel balls, rods and steel wool. Matrices of the grooved plate type and of the expanded metal screens found the widest application. Mekhanobrcherment Institute has developed a new type of matrix, namely the grooved-screens matrix.

\section{A STUDY OF THE GROOVED PLATE MATRIX FOR HIMS}

The matrix of this type was first proposed by Humboldt Wedag Co. for the application in their Jones high-intensity magnetic separators. It is claimed that approximately 150 separators of such a design have been manufactured and delivered to users since 1968 . The current standard sizes are the $\mathrm{P}-40$ single-rotor separator with capacity of $0.5 \mathrm{t} / \mathrm{h}$ and DP-317 commercial two-rotor separator with capacity of $120 \mathrm{t} / \mathrm{h}$. The largest standard size separator is the DP-335 model with capacity of $250 \mathrm{t} / \mathrm{h}$. The $4 \mathrm{R}$ grooved plates ( 4 grooves per inch of width) are used in these separators. The most widely used type of the matrix is the $8 \mathrm{R}$ plate. A gap (a distance between opposite plate teeth) has the following values: $4 R$ plates: $5 \mathrm{~mm}, 8 \mathrm{R}$ plates: $1.2 \mathrm{~mm}, 1.8 \mathrm{~mm}$ and $2.5 \mathrm{~mm}, 12 \mathrm{R}$ plates: $0.5 \mathrm{~mm}$ and $0.8 \mathrm{~mm}$. The standard height of the plates is $220 \mathrm{~mm}$ [1]. Typical grooved-plate matrix is shown in Fig. 1.

Mekhanobrchermet Institute, jointly with Humboldt Wedag, carried out tests in order to investigate a possibility of application of the Jones separators and their matrices for separation of oxidised ferruginous quartzites from Krivoy Rog.

In 1980 such tests were carried out using the $\mathrm{P}-40$ separator. The $8 \mathrm{R}$ and $12 \mathrm{R}$ grooved plates were used as the matrix, with the width of the gap being equal to $0.5,0.8$ and $1.0 \mathrm{~mm}$. It was established that the best results as far as grade of the magnetic product and the recovery of iron are concerned could be attained using $12 \mathrm{R}$ grooved plates with 0.5 to $0.8 \mathrm{~mm}$ gap. However, the production process in this case was not stable. Intensive clogging of the gaps between adjacent grooves and between opposite plates occurred. When using $8 \mathrm{R}$ grooved plates with $1 \mathrm{~mm}$ gap and $95 \%-45 \mu \mathrm{m}$ size fraction, the recovery of magnetite of $90 \%$ was achieved while the recovery of hematite and of iron hydroxides and carbonates amounted to $82 \%$ and $60 \%$, respectively. The recoveries of various size fractions were as follows: 


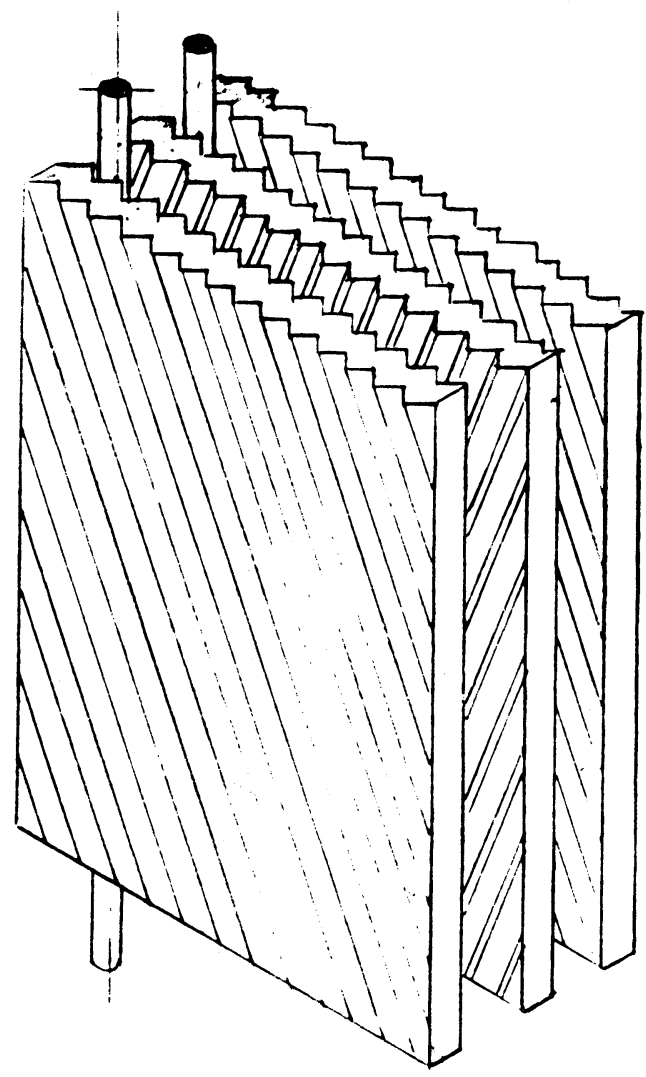

Fig. 1. The grooved-plate matrix

$\begin{array}{ll}-160+45 \mu \mathrm{m} & 97 \% \\ -45+10 \mu \mathrm{m} & 85 \% \\ -10+5 \mu \mathrm{m} & 60 \% \\ -5 \mu \mathrm{m} & 35 \%\end{array}$

In 1983 the tests of matrices in the production-scale DP-317 separators installed at the Mikhailovsky Mining and Beneficiation Complex (Russia, Zheleznogorsk) were conducted. Grooved plates were used for both types of the separator; the width of the gap between the plates in one separator was $0.8 \mathrm{~mm}$ while in the other the gap was equal to $2.5 \mathrm{~mm}$. 
With the $0.8 \mathrm{~mm}$ gap, extensive clogging of the gaps with undischarged material took place, in spite of efficient protection of the pulp from tramp iron and other impurities. When automatic air-water flushing device was used, the desired effect was not achieved. It was concluded that the $0.8 \mathrm{~mm}$ gap cannot be used under industrial conditions. With the $2.5 \mathrm{~mm}$ gap the matrix regeneration was quite efficient. The process parameters were, however, affected by the fact that with 2.5 $\mathrm{mm}$ gap the DP-317 Jones separator generated the magnetic field of 0.85 Tesla which was not sufficient for separation of oxidised ferruginous quartzites.

The grooved-plate matrix was used by Mekhanobr Institute (St. Petersburg, Russia) in the two-rotor 1/2 ERFM-100 pilot-scale separator with throughput of $5 \mathrm{t} / \mathrm{h}$ and in the production-scale separator 2/2 ERFM-160 with throughput of $50 \mathrm{t} / \mathrm{h}$. These separators are characterised, compared to the Jones separator, by the reduced height of the separation zone $(150 \mathrm{~mm}$ vs $220 \mathrm{~mm})$. The pitch of the grooves on the plates of these separators was $3.5 \mathrm{~mm}$ which is close to the pitch of the plates in the Jones separator. The gap used was $2.5 \mathrm{~mm}$.

Using the $1 / 2$ ERFM-100 separator for the first stage of separation of oxidised ferruginous quartzites, of size fraction $80 \%-74 \mu \mathrm{m}$, the magnetic middlings with $50 \% \mathrm{Fe}$ at $85 \%$ recovery were produced. The basic metal losses were associated with $-20 \mu \mathrm{m}$ size fraction. For this reason, this separator could not be used at the second separation stage ( 90 to $95 \%-45 \mu \mathrm{m}$ size fraction).

The matrix of grooved plates was installed in both rotors of the 2/2 ERFM-160 separator. The plate height was $150 \mathrm{~mm}$, the pitch of the grooves $3.5 \mathrm{~mm}$ and the gap between the plates $1.8 \mathrm{~mm}$. When separating oxidised ferruginous quartzites in the first separation stage, in two passes, with size $75 \%-74 \mu \mathrm{m}$, the magnetic product was produced with the grade of $52 \% \mathrm{Fe}$ at $82 \%$ recovery. In the second stage, in two passes, with $90 \%-45 \mu \mathrm{m}$ size fraction, the concentrate with $62.3 \%$ Fe was produced. The Fe content at $-10 \mu \mathrm{m}$ was $52.55 \%$. The matrix clogging by undischarged material was not observed.

Comparison of the magnetic field parameters, the matrix parameters and of the efficiency of the separation process of the Mekhanobr Institute separator and of the Jones separator leads to a conclusion that the difference is caused by the reduced height of the grooved plates installed in the Mekhanobr Institute separators. 
Several series of tests were conducted using the grooved plates fabricated according to the drawings of the Gipromashugleobogashcheniye Institute (Lugansk, Ukraine). The height of these plates was $220 \mathrm{~mm}$, the pitch of the grooves $3.2 \mathrm{~mm}$ and the slope of the grooves $90^{\circ}$ (straight tooth plates) and $60^{\circ}$ (skewed tooth plates). The plates were joined in blocks. The gap between the plates was 3.6 to $4 \mathrm{~mm}$. The tests were conducted using the ERFM-1 production-scale three-rotor magnetic separator of $100 \mathrm{t} / \mathrm{h}$ capacity. The separator was installed at the Central Mining and Beneficiation Complex (Krivoy Rog, Ukraine).

The upper rotor of the separator was equipped with straight tooth plates and the middle and lower rotors with skewed tooth plates. The magnetic induction in the upper rotor was 0.3 to $0.4 \mathrm{~T}$ and in the middle and lower rotors 1.2 to $1.35 \mathrm{~T}$. The measurements of the magnetic induction were carried out in the working space between the grooved plates. The non-magnetics from the upper rotor were scavenged in the middle rotor and the non-magnetics from the middle rotor were scavenged in the lower rotor. When treating the oxidised ferruginous quartzites in the first separating stage ( $74 \%-74 \mu \mathrm{m}$ size fraction) from an ore containing $36 \%$ $\mathrm{Fe}$, the magnetite middlings with $53 \% \mathrm{Fe}$ and tailings with $11.9 \% \mathrm{Fe}$ were produced. At the second separation stage $(92 \%-45 \mu \mathrm{m}$ size fraction), the magnetic concentrate with $61.8 \% \mathrm{Fe}$ and the tailings with $25.6 \% \mathrm{Fe}$ were produced.

Over a long period (from 1989) observations of the performance of the grooved plate matrix were conducted in the production section of the Central Mining and Beneficiation Complex where five 6-ERM 35/315 magnetic separators were installed. This section beneficiates the oxidised ferruginous quartzites. These observations showed that with reliable protection of separators from magnetite and tramp iron, the grooved plates with the $4 \mathrm{~mm}$ gap were technologically reliable. Some decrease in the process parameters, by comparison with those for the plates with the $2.5 \mathrm{~mm}$ gap could be compensated for by an increased magnetic induction in the separator. At the same time, in the second separation stage, the grooved plates did not provide sufficient recovery of fine fractions (5 to $10 \mu \mathrm{m}$ ).

The tests carried out using difficult-to-treat iron ores (limonite and siderite) showed that separation of these ores using grooved plates was inefficient. 


\section{A STUDY OF MATRICES OF EXPANDED METAL SCREENS}

The matrices of the expanded metal type were proposed for the first time for the MRVK separators (Czechoslovakia) and Eriez Magnetics (USA). These matrices were further employed e.g. in the SALA HGMS separators (Sweden). The SALA separator uses a steel-clad magnetic system with vertical direction of the magnetic field. Separation is carried out in an aqueous medium and the height of the separation zone is $150 \mathrm{~mm}$. The maximum magnetic induction measured in the separation zone without the matrix was $1.4 \mathrm{~T}$. The matrix consists of horizontally arranged expanded metal screens, shown in Fig. 2.



Fig. 2 The expanded metal matrix

Thickness of the screens is $0.25 \mathrm{~mm}, 0.5 \mathrm{~mm}, 0.6 \mathrm{~mm}$ and $0.9 \mathrm{~mm}$. The length of aperture ranges from 3.2 to $22 \mathrm{~mm}$ while the width ranges from 1.3 to $8 \mathrm{~mm}$. The screens can be either separated by spacers or they can be closely packed. Thickness of the spacers is within the $0.4 \mathrm{~mm}$ to $2.5 \mathrm{~mm}$ range. During the assembly of the matrix the screens were closely packed. A pulp which flows through the matrix is affected by the high-gradient magnetic field. The field gradient is determined by the matrix surface and by the number of sharp edges [2]. 
Technological tests of the matrices were carried out on the carousel 120 model separator using oxidised ferruginous quartzites from the Southern Mining and Beneficiation Complex (SMBC) and Novokrivoyrozhsky Mining and Beneficiation Complex (NKMBC). The separation circuit comprised two stages of separation. In the first stage, the feed ore (raw material) of the $75-80 \%-45 \mu \mathrm{m}$ size was treated; in the second stage the magnetic product from the first stage, with $88-90 \%-45$ $\mu \mathrm{m}$ size was upgraded. The separation parameters of the oxidised ore, when using the expanded metal matrix are summarised in Table I.

Table I Magnetic separation results of oxidised quartzites using the Sala 120 carousel separator with expanded metal matrix.

\begin{tabular}{|c|c|c|c|c|c|c|c|}
\hline \multirow{2}{*}{ Ore } & \multirow{2}{*}{ Matrix } & \multirow{2}{*}{$\mathrm{B}(\mathrm{T})$} & \multicolumn{3}{|c|}{ Fe Content (\%) } & \multirow{2}{*}{$\begin{array}{c}\text { Mass of } \\
\text { mags (\%) }\end{array}$} & \multirow{2}{*}{$\begin{array}{c}\text { Recovery } \\
\text { into mags } \\
(\% \mathrm{Fe})\end{array}$} \\
\hline & & & Feed & Mags & Non-mags & & \\
\hline \multicolumn{8}{|c|}{ 1st Stage of Separation } \\
\hline SMBC & $\begin{array}{c}\mathrm{N} 3 / 0,0.25 \\
\text { mm thick, } \\
\text { spacers } \\
1.1 \mathrm{mmm} \text {, } \\
\text { mesh } \\
3.2 \times 1.3\end{array}$ & 0.5 & 37.9 & 54.2 & 12.2 & 61.2 & 87.5 \\
\hline NKMBC & $\begin{array}{c}\mathrm{N} 51 ; 0.6 \\
\text { mm thick, } \\
\text { no spacers } \\
\text { mesh } \\
13.5 \times 5.1\end{array}$ & 0.5 & 37.6 & 56.7 & 13.0 & 56.3 & 84.9 \\
\hline \multicolumn{8}{|c|}{ 2nd Stage Separation } \\
\hline NKMBC & $\begin{array}{c}\mathrm{N} 3 / 0,0.25 \\
\mathrm{~mm} \text { thick} \\
\text { spacers } \\
1.1 \mathrm{~mm} \\
\text { mesh } \\
3.2 \times 1.3\end{array}$ & 0.5 & 54.4 & 59.2 & 35.1 & 80.1 & 87.2 \\
\hline NKMBC & $\begin{array}{c}\mathrm{N} 51 ; 0.6 \\
\mathrm{~mm} \text { thick, } \\
\text { no spacers } \\
\text { mesh } \\
13.5 \times 5.1\end{array}$ & 0.5 & $54 \ldots 1$ & 61.6 & 32.0 & 74.5 & 84.9 \\
\hline
\end{tabular}


Using the oxidised quartzites from SMBS, comparable tests of two matrix types, N51 (thickness without spacers was $0.6 \mathrm{~mm}$, screen mesh sizes $13.5 \times 5.1 \mathrm{~mm}$ ) and $\mathrm{N} 140$ (thickness without spacers was $0.5 \mathrm{~mm}$, screen mesh sizes $7.1 \times 2.5 \mathrm{~mm}$ ) were performed with $75-80 \%-45 \mu \mathrm{m}$ size fraction and the matrix loading of $0.3 \mathrm{~g} / \mathrm{cm}^{3}$ for the N51 matrix, a concentrate with $58.4 \% \mathrm{Fe}$ and tailings with $23.8 \%$ Fe were produced. With $88-92 \%-45 \mu \mathrm{m}$ size fraction and the matrix loading of $0.3 \mathrm{~g} / \mathrm{cm}^{3}$ for the N140 matrix, the concentrate of the same grade at lower Fe content in the tailings $(18.1 \% \mathrm{Fe})$ was obtained.

Commercial tests with expanded metal matrix were conducted using the experimental EKMF-600 separator at the Novokrivoyrozhsky Mining and Beneficiation Complex (Krivoy Rog, Ukraine). The matrix height in this separator was $150 \mathrm{~mm}$ and the expanded metal screens were manufactured from metal 0.6 $\mathrm{mm}$ thick. The screen mesh sizes were $13.5 \times 5.1 \mathrm{~mm}$. Oxidised ferruginous quartzites were tested in a two-stage circuit (one separation pass per stage). From an ore containing $35.2 \% \mathrm{Fe}$ a concentrate with $60.2 \% \mathrm{Fe}$ was produced, while the Fe content in the tailings was $17.2 \%$ and the mass yield into the concentrate was $41.8 \%$. The recovery into the concentrate was $71.5 \%$.

Comparison of expanded metal matrix and grooved plates showed the following:

The expanded metal matrix is more efficient. When separating the oxidised quartzites using the expanded metal matrix, it is possible to obtain, in one pass, results comparable to those obtained when using a three-pass separation with grooved-plate matrix.

An application of expanded metal matrix allows to work at lower magnetic induction in the gap, compared to that with grooved plates.

With an increase in the thickness of the expanded metal screens the grade of the magnetic product improves and the recovery of iron decreases.

A drawback of the expanded metal matrix is that it performs efficiently in aqueous medium only, while in the air (in the pulp flow) it often clogs with magnetic material. 


\section{A STUDY OF THE SCREENS-GROOVED PLATE MATRIX}

The screens-grooved plate matrix consists of grooved plates between which expanded metal screens are packed, as is shown in Fig. 3.

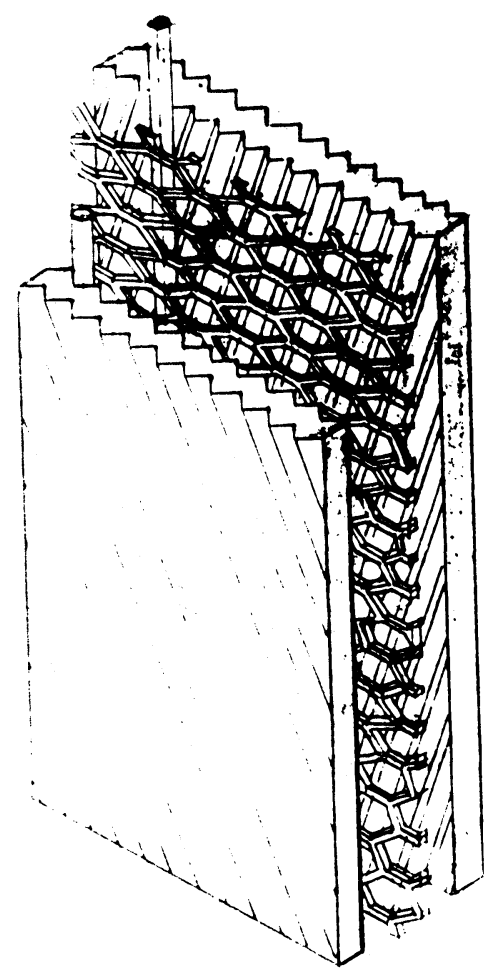

Fig. 3 The screen-grooved plate matrix

An introduction of the expanded metal screens allows more efficient use of the "dead" zone between the plates. Advantages of the screens-grooved plate matrix are as follows:

An increase of the gradient of the magnetic field in the separation zone as a result of introduction of the screens with a large number of sharp edges. 
An increase of the magnetic induction in the separation zone as a result of introduction of ferromagnetic material into the zone.

The self-cleaning of the matrix due to the vibrations of the screens by the polarity reversal in the matrix.

When treating oxidised ferruginous quartzites it is advisable to use the screen-grooved plate matrix in the last stage of separation, for the recovery of hydroxides, iron carbonates and fine hematite fraction of 10 to $15 \mu \mathrm{m}$.

During the separation of weakly magnetic ores, e,g, limonite and siderite, the application of the screen-grooved plate matrix allows to use rotor magnetic separators with horizontal magnetic field (it is known that when using the grooved plates, these ores are beneficiated with low efficiency).

Laboratory tests were conducted using oxidised ferruginous quartzites with screen-grooved plate matrix in the lower rotor of the 6-ERM 35/315 separator (2nd stage of separation). Table II shows that the application of the screen-grooved plate matrix instead of grooved plates with the same gap increases the grade of the magnetic concentrate by $1.9 \%$ and increases the recovery of iron by $8.1 \%$.

A study of high-intensity magnetic separation of limonite and siderite ores from the Kremikovsky Iron and Steel Complex (Bulgaria), with different matrices was performed. The separation was carried out in three passes with the scavenging of the non-magnetic fractions. Magnetic induction in the final stage was $1.2 \mathrm{~T}$. Results of the tests are presented in Table III.

It can be seen that the application of the screen-grooved plate matrix when treating the limonite ore increases considerably the recovery of iron into the magnetic product, as a result of the recovery of the intergrown particles, which, however, results in the reduction of the grade of the concentrate. When treating liberated siderite ore, the recovery increases without reducing the grade of the magnetic product. 
Table II Results of magnetic separation of oxidised quartzites using different matrices.

\begin{tabular}{|c|c|c|c|c|c|c|}
\hline \multirow{2}{*}{\multicolumn{2}{|c|}{ Matrix }} & \multicolumn{3}{|c|}{ Fe Content $(\%)$} & \multirow{2}{*}{$\begin{array}{l}\text { Mass of } \\
\text { mags }(\%)\end{array}$} & \multirow{2}{*}{$\begin{array}{c}\text { Recovery } \\
\text { into mags } \\
(\% \mathrm{Fe})\end{array}$} \\
\hline & & Feed & Mags & Non-mags & & \\
\hline \multirow{2}{*}{$\begin{array}{l}\text { Grooved } \\
\text { plates }\end{array}$} & \begin{tabular}{|c|} 
Skewed \\
tooth plates, \\
$3.5 \times 60 \times 200$ \\
gap $4 \mathrm{~mm}$
\end{tabular} & 33.1 & 52.1 & 21.8 & 37.8 & 59.8 \\
\hline & \begin{tabular}{|c|} 
Skewed \\
tooth plates, \\
$3.5 \times 60 \times 200$, \\
gap $2.2 \mathrm{~mm}$
\end{tabular} & 33.3 & 52.4 & 19.4 & 42.2 & 66.4 \\
\hline $\begin{array}{c}\text { Screen-groo } \\
\text { ved plates }\end{array}$ & \begin{tabular}{|c|} 
shewed \\
tooth plates, \\
$3.5 \times 60 \times 200$, \\
mesh 1.8 \\
mm, gap 6 \\
mm
\end{tabular} & 33.5 & 54.0 & 18.8 & 42.1 & 67.9 \\
\hline
\end{tabular}

Table III Results of magnetic separation of Kremikovsky ores using different matrices.

\begin{tabular}{|c|c|c|c|c|c|c|c|c|c|c|}
\hline \multirow{3}{*}{ Matrix } & \multicolumn{5}{|c|}{ Limonite ore } & \multicolumn{5}{|c|}{ Siderite ore } \\
\hline & \multicolumn{3}{|c|}{ Fe Content $(\%)$} & \multirow{2}{*}{$\begin{array}{c}\text { Mass } \\
\text { of } \\
\text { mags } \\
(\%)\end{array}$} & \multirow{2}{*}{$\begin{array}{c}\mathrm{Fe} \\
\text { Recove } \\
\text { ry (\%) }\end{array}$} & \multicolumn{3}{|c|}{ Fe Content $(\%)$} & \multirow{2}{*}{$\begin{array}{c}\text { Mass } \\
\text { of } \\
\text { mags } \\
(\%)\end{array}$} & \multirow{2}{*}{$\begin{array}{c}\text { Fe } \\
\text { Recove } \\
\text { ry }(\%)\end{array}$} \\
\hline & Feed & Mags & $\begin{array}{l}\text { Non- } \\
\text { mags }\end{array}$ & & & Feed & Mags & $\begin{array}{l}\text { Non- } \\
\text { mags }\end{array}$ & & \\
\hline $\begin{array}{c}\text { Groov- } \\
\text { ed } \\
\text { plates } \\
2 \mathrm{~mm} \\
\text { gap }\end{array}$ & 29.9 & 46.4 & 24.9 & 23.2 & 36.0 & 24.4 & 32.5 & 10.4 & 63.4 & 83.4 \\
\hline $\begin{array}{c}\text { Screen } \\
\text { groov- } \\
\text { ed } \\
\text { plates } \\
3 \mathrm{~mm} \\
\text { gap }\end{array}$ & 29.9 & 40.8 & 14.8 & 58.1 & 79.3 & 24.4 & 31.9 & 2.4 & 74.6 & 97.5 \\
\hline
\end{tabular}


Similar tests were conducted using siderite and limonite ores from the Bakal'sky Mine (Bakal, Russia). Separation of these ores was carried out using the rotor-type high-intensity magnetic separator in three passes, with the scavenging of the non-magnetic fractions. The magnetic induction at three stages of separation was as follows: for separation of the siderite ore: $0.4,1.2$ and $1.3 \mathrm{~T}$, for limonite ore: $1 ., 1.2$ and $1.3 \mathrm{~T}$. Two matrices were compared: straight-tooth grooved plates and screen-grooved plate matrix. The size fractions of the feed were $75 \%-74 \mu \mathrm{m}$ and $90 \%-74 \mu \mathrm{m}$, respectively. The results of the tests are summarised in Table IV.

Table IV Magnetic separation of the Bakal iron ores

\begin{tabular}{|c|c|c|c|c|c|c|}
\hline \multirow[b]{2}{*}{ Size } & \multirow[b]{2}{*}{ Matrix } & \multicolumn{3}{|c|}{ Fe Content $(\%)$} & \multirow{2}{*}{$\begin{array}{l}\text { Mass of } \\
\text { mags }(\%)\end{array}$} & \multirow{2}{*}{$\begin{array}{c}\text { Recovery } \\
(\% \mathrm{Fe})\end{array}$} \\
\hline & & Feed & Mags & Non-mags & & \\
\hline \multicolumn{7}{|c|}{ Siderite Ore } \\
\hline $\begin{array}{l}75 \%-74 \\
\text { microns }\end{array}$ & $\begin{array}{l}\text { grooved } \\
\text { plates }\end{array}$ & 28.2 & 32.7 & 12.2 & 78.0 & 90.0 \\
\hline $\begin{array}{l}75 \%-74 \\
\text { microns }\end{array}$ & \begin{tabular}{|c|} 
screen- \\
grooved \\
plate matrix
\end{tabular} & 28.2 & 32.0 & 9.0 & 83.5 & 94.7 \\
\hline $\begin{array}{l}90 \%-74 \\
\text { microns }\end{array}$ & $\begin{array}{c}\text { grooved } \\
\text { plates }\end{array}$ & 28.2 & 33.2 & 15.7 & 71.4 & 84.0 \\
\hline $\begin{array}{l}90 \%-74 \\
\text { microns }\end{array}$ & \begin{tabular}{|c|} 
screen- \\
grooved \\
plate matrix
\end{tabular} & 28.2 & 32.8 & 13.8 & 75.8 & 88.2 \\
\hline \multicolumn{7}{|c|}{ Limonite Ore } \\
\hline $\begin{array}{l}75 \%-74 \\
\text { microns }\end{array}$ & $\begin{array}{c}\text { grooved } \\
\text { plate }\end{array}$ & 49.5 & 53.6 & 43.5 & 59.4 & 64.3 \\
\hline $\begin{array}{l}75 \%-74 \\
\text { microns }\end{array}$ & \begin{tabular}{|c|} 
screen- \\
grooved \\
plate matrix \\
\end{tabular} & 49.5 & 53.1 & 41.0 & 70.2 & 75.3 \\
\hline $\begin{array}{l}90 \%-74 \\
\text { microns }\end{array}$ & $\begin{array}{l}\text { grooved } \\
\text { plate }\end{array}$ & 49.5 & 54.8 & 44.7 & 47.5 & 52.6 \\
\hline $\begin{array}{l}90 \%-74 \\
\text { microns }\end{array}$ & $\begin{array}{c}\text { screen- } \\
\text { grooved } \\
\text { plate matrix }\end{array}$ & 49.5 & 54.0 & 42.0 & 62.5 & 68.2 \\
\hline
\end{tabular}


It follows from Table IV that:

Replacement of the grooved-plate matrix by the screen-grooved plate matrix for the beneficiation of the difficult-to-treat iron ore results in significant increase in the recovery of iron at the cost of certain reduction in the grade of the magnetic product. For $1 \%$ reduction in the grade the recovery increased by 6 to $10 \%$ for the siderite ore and by 11 to $12 \%$ for the limonite ore.

The increase in the recovery is specifically significant for fine ore grinding.

A matrix assembly of 13 blocks was manufactured to equip the lower rotor of the 3-ERM-60 three-rotor magnetic separator with throughput of $2 \mathrm{t} / \mathrm{h}$. Parameters of the matrix blocks were as follows: height: $220 \mathrm{~mm}$, length along the rotor circumference: $75 \mathrm{~mm}$, width of separation channels: $3.2 \mathrm{~mm}$, slope of the grooves: $60^{\circ}$, overall gap between opposite plates: $5.35 \mathrm{~mm}$, mesh dimensions of the expanded metal screens: $13.5 \times 5.1 \mathrm{~mm}$.

Technological tests of the 3-ERM separator in continuous mode of operation, when processing oxidised ferruginous quartzites from SMBC and NKMBC, in the first and second stages of separation were conducted. The upper and middle rotors of the separator were equipped with grooved plates while the lower rotor comprised screen-grooved plate matrix. The process parameters of separation are given in Table V; mineral composition in shown in Table VI and size analysis of the recovered fractions is shown in Table VII.

It may be concluded from these Tables that the application of the screen-grooved plate matrix ensures high efficiency of the separation process and satisfactory recovery of fine size fractions and of very weakly magnetic minerals (iron hydroxides and iron carbonates).

According to the Mekhanobrchermet proposal, the Gipromashugleobogashchenie Institute developed the screen-grooved plate matrix design for production-scale commercial 6 ERM 35/315 magnetic separator. Proposals for a supply of the separator with this type of matrix will be presented according to the results of the metallurgical studies. 
Table V Results of magnetic separation of oxidised quartzites using 3-ERM-60 separator, at the magnetic induction of $1.2 \mathrm{~T}$.

\begin{tabular}{|c|c|c|c|c|c|c|}
\hline \multicolumn{2}{|c|}{ Size Distribution (\%) } & \multicolumn{3}{|c|}{ Fe Content (\%) } & \multirow{2}{*}{$\begin{array}{c}\text { Mass of } \\
\text { mags }(\%)\end{array}$} & \multirow{2}{*}{$\begin{array}{l}\text { Recovery of } \\
\text { Fe into } \\
\text { mags }(\%)\end{array}$} \\
\hline-74 microns & -45 microns & Feed & Mags & Non-mags & & \\
\hline \multicolumn{7}{|c|}{ 1st Stage of Separation } \\
\hline 87.0 & 74.0 & 38.9 & 57.1 & 15.9 & 55.8 & 81.9 \\
\hline \multicolumn{7}{|c|}{ 2nd Stage of Separation } \\
\hline 89.8 & 84.0 & 57.6 & 62.7 & 38.8 & 78.7 & 85.7 \\
\hline
\end{tabular}

Table VI Mineral composition of the separation products from the 3-ERM-60 separator

\begin{tabular}{||c|c|c|c|c|c|c|c|c|c||}
\hline \multirow{2}{*}{ Product } & \multicolumn{7}{|c|}{ Fe Content (\%) } & \multicolumn{5}{c||}{ Fe Recovery (\%) } \\
\cline { 2 - 9 } & $\begin{array}{c}\text { Magne- } \\
\text { tite }\end{array}$ & $\begin{array}{c}\text { Hematite } \\
\text { or } \\
\text { martite }\end{array}$ & $\begin{array}{c}\text { Hydro- } \\
\text { xides }\end{array}$ & $\begin{array}{c}\text { Carbo- } \\
\text { nates }\end{array}$ & $\begin{array}{c}\text { Magne- } \\
\text { tite }\end{array}$ & $\begin{array}{c}\text { Hematite } \\
\text { or } \\
\text { martite }\end{array}$ & $\begin{array}{c}\text { Hydro- } \\
\text { xides }\end{array}$ & $\begin{array}{c}\text { Carbo- } \\
\text { nates }\end{array}$ \\
\hline Feed & 0.70 & 32.20 & 5.70 & 0.30 & 100.00 & 100.00 & 100.00 & 100.00 \\
\hline Mags & 1.20 & 49.10 & 6.30 & 0.50 & 98.30 & 85.30 & 61.80 & 93.20 \\
\hline $\begin{array}{l}\text { Non- } \\
\text { mags }\end{array}$ & 0.07 & 10.80 & 4.90 & 0.10 & 1.70 & 14.70 & 38.20 & 6.80 \\
\hline \multicolumn{70}{||c|}{ 2nd Stage of Separation } \\
\hline Feed & 1.70 & 47.20 & 7.90 & 0.80 & 100.00 & 100.00 & 100.00 & 100.00 \\
\hline Mags & 2.10 & 52.50 & 7.20 & 0.90 & 97.00 & 87.40 & 71.60 & 88.40 \\
\hline $\begin{array}{l}\text { Non- } \\
\text { mags }\end{array}$ & 0.30 & 27.80 & 10.50 & 0.20 & 3.00 & 12.60 & 28.40 & 11.60 \\
\hline \hline
\end{tabular}


Table VII Size analysis of products from the 3-ERM-60 separator

\begin{tabular}{|c|c|c|c|c|c|c|c|c|c|c|}
\hline \multirow[b]{2}{*}{$\begin{array}{l}\text { Produ- } \\
\text { cts }\end{array}$} & \multicolumn{5}{|c|}{ Size fraction, in microns (\%) } & \multicolumn{5}{|c|}{ Size fraction recovery $(\%)$} \\
\hline & 100.0 & $\begin{array}{c}-100+ \\
74\end{array}$ & $\begin{array}{r}-74 \\
+45\end{array}$ & $\begin{array}{r}-45 \\
+10\end{array}$ & $\begin{array}{l}-10 \\
+0\end{array}$ & 100.0 & $\begin{array}{l}-100 \\
+74\end{array}$ & $\begin{array}{r}-74 \\
+36\end{array}$ & $\begin{array}{l}-45 \\
+10\end{array}$ & $\begin{array}{l}-10 \\
+0\end{array}$ \\
\hline \multicolumn{11}{|c|}{ 1st stage of separation } \\
\hline Feed & 6.5 & 6.0 & 14.8 & 53.8 & 18.9 & 100.0 & 100.0 & 100.0 & 100.0 & 100.0 \\
\hline Mags & 6.8 & 6.6 & 16.4 & 60.9 & 9.3 & 58.5 & 61.5 & 62.0 & 63.3 & 27.5 \\
\hline $\begin{array}{l}\text { Non- } \\
\text { mags }\end{array}$ & 6.0 & 5.3 & 12.8 & 44.8 & 31.1 & 41.5 & 38.5 & 38.0 & 36.7 & 72.5 \\
\hline \multicolumn{11}{|c|}{ 2nd stage of separation } \\
\hline Feed & 1.3 & 2.0 & 5.2 & 66.6 & 24.9 & 100.0 & 100.0 & 100.0 & 100.0 & 100.0 \\
\hline Mags & 1.4 & 2.0 & 5.0 & 76.3 & 15.3 & 84.6 & 78.6 & 75.5 & 90.0 & 48.3 \\
\hline $\begin{array}{l}\text { Non- } \\
\text { mags }\end{array}$ & 1.2 & 2.0 & 5.9 & 30.8 & 60.1 & 15.4 & 21.4 & 24.5 & 10.0 & 51.7 \\
\hline
\end{tabular}

\section{CONCLUSIONS}

Technological possibilities to use various matrices in high-intensity magnetic separators were discussed. The application of screen-grooved plate matrix was shown to improve the process parameters when applied to separation of finely disseminated hematite, limonite and siderite ores.

\section{ACKNOWLEDGMENTS}

The author acknowledges contribution of the following persons who participated in the project: Z.P. Armashova, I.P. Bogdanova, T.B. Ganzenko, Kh. U. Koval'chuk, A.M. Kutin, L.A. Lomovtsev, Yu.V. Narizhnyak, G.I. Notovich, I.D. Roizen, Ye. A. Tytlyanov and R.S. Ulubabov. 


\section{REFERENCES}

[1] J.A. Bartnik et al.: The Jones WHIMS using wide gaps for beneficiation of martised iron ores and production of coarse-grained sinter feed from hematite iron ores. Paper presented at the Colloquium on Magnetic Separation in Mineral Industry, Randburg, South Africa (1986)

[2] Continuous high-gradient magnetic separators for mineral processing. SMI Bulletin No. S79-0001.

Keywords: high-intensity magnetic separation, matrix, hematite, siderite, limonite

V.M. Maly: For biography see Magn. Electr. Sep. 4 (1992), 58 